\title{
David Sanders: um gigante do Movimento pela Saúde dos Povos
}

\author{
David Sanders: a giant of the People's Health Movement
}

Camila Giugliani $\mathbf{1 , 2}$

DOI: 10.1590/0103-11042020S119

OUTUBRO DE 2005. O LIVRO 'THE STRUGGLE FOR HEALTH'1, publicado em 1985, caiu nas minhas mãos. Mandado por minha mãe, como um presente, na véspera da minha partida para trabalhar em uma missão humanitária em Angola. Revisitando o livro, 14 anos depois, releio algumas frases que tanto me marcaram. Justamente naquele momento, quando eu estava me perguntando exatamente o que o autor do livro se propunha a explicar:

Por que as pessoas, especialmente as crianças, ainda morrem em grande número, pelo mundo afora, por causas totalmente evitáveis? Por que razão os cuidados apropriados em saúde não estão disponíveis para todos os indivíduos no mundo? Que mudanças podem ser feitas para melhorar essa situação?1(7). [tradução da autora].

Nas páginas seguintes, o prefácio termina com um 'tapa na cara', um chamado para a ação: "Por muito tempo, a saúde foi vista como um assunto à parte dos problemas reais da sociedade. Chegou a hora de corrigir a balança.[tradução da autora]"'(12). Escrito em 1984, em Harare, Zimbabwe, assinado por D.M.S. Era David M. Sanders. Mas quem era essa pessoa, que escrevia coisas tão verdadeiras, de forma tão assertiva e inequívoca? Um médico pediatra, africano, que parecia saber muito bem do que estava falando.

Seguindo as próximas páginas, muitas fotos impactantes, de crianças gravemente desnutridas, de famílias vivendo em condições desumanas, favelas, lixo, falta de saneamento, pessoas trabalhando arriscadamente no mercado informal. David escrevia sobre a associação das consequências nefastas das injustiças sociais na situação de saúde das pessoas. Fazia a gente entender como o estado de saúde é tão diretamente influenciado pelas condições de vida, por sua vez afetadas por questões políticas e econômicas. Ele falava sobre os determinantes sociais da saúde. As respostas para as perguntas iniciais estavam nas causas estruturais das doenças, que iam muito além da oferta de serviços de saúde, e era sobre isso que o David falava com tanta

1 Universidade Federal do Rio Grande do Sul (UFRGS) - Porto Alegre (RS), Brasil. giugli@hotmail.com

2 Movimento pela Saúde dos Povos (MSP) - Porto Alegre (RS), Brasil. firmeza e propriedade. Era exatamente o que eu precisava ler para reafirmar o sentimento de indignação com as inaceitáveis desigualdades em saúde.

Tudo fazia sentido. Fui para Angola, fiquei um ano e voltei para Porto Alegre. Com as mesmas inquietações e um sentimento de indignação ainda maior. Era 2007, comecei o doutorado em epidemiologia, sempre inspirada pelo que havia lido no livro do David. Até então, para mim, ele era uma referência distante de médico, escritor e professor. Até que o meu orientador, Bruce 
Duncan, outra referência de pesquisador comprometido, que compartilhava da mesma visão com relação às causas estruturais das doenças, um dia me contou que queria convidar o professor David Sanders para ser um dos palestrantes do Congresso Internacional de Epidemiologia, que ocorreria no ano seguinte em Porto Alegre. Além disso, falou-me que uma colega dentista, Denise Antunes, tinha entrado em contato, para organizar alguma atividade com o David, que estaria vindo visitar Porto Alegre em julho daquele ano. Convidou-me para ajudar a organizar as atividades e para traduzir a palestra que Daviddaria na Faculdade de Odontologia da Universidade Federal do Rio Grande do Sul (UFRGS).

A Denise havia feito mestrado na África do Sul, na Western Cape University, inspirada pelo David Sanders e pelo People's Health Movement (PHM). Foi nessa ocasião que conheci o Movimento pela Saúde dos Povos (MSP). Durante a estada do David, conversamos muito. Tudo que eu havia lido, estava sendo novamente reafirmado e de forma ainda mais contundente, enfática, direto no ponto, como só ele sabia ser. Também foi no encontro com David que conheci uma visão diferente de Atenção Primária à Saúde, ou comprehensive Primary Health Care, que compreendia os determinantes sociais da saúde e da doença. Como médica de família e comunidade, pude ampliar meus referenciais e minha capacidade crítica. David ensinava muito sobre isso. Sabia ser crítico, irônico na medida certa. Suas frases eram curtas e certeiras. Então, antes de partir, ele desafiou a Denise e a mim:

Vocês têm que formar o círculo do MSP aqui!

Sim, nós queremos, e como fazemos?

Reúnam-se! Vocês já têm aqui três, quatro, cinco pessoas! Comecem!

E ainda com David em Porto Alegre (POA), fizemos o primeiro encontro do embrionário
MSP Brasil POA, em uma sala de aula do Hospital Materno-Infantil Presidente Vargas.

Seguiram-se vários encontros, pessoas vieram, algumas voltaram, outras não. Fluido como é o Movimento. Por volta de setembro, ainda em 2007, pipocou no meu e-mail uma chamada para um curso da International People's Health University (IPHU) em Savar, Bangladesh, berço do PHM. Escrevi para o David, perguntando o que achava, e ele me estimulou a ir. Em novembro, por 14 dias em imersão, estávamos, Denise e eu, nas dependências de Gonoshasthaya Kendra, conhecido como GK. Conhecemos lá muitos outros ativistas do PHM, e o curso foi um motor muito importante para seguirmos na construção do Círculo do MSP Brasil em Porto Alegre. Saímos de lá com uma 'missão impossível': organizar um curso da IPHU em Porto Alegre no ano seguinte.

Em setembro de 2008, recebemos mais de 50 ativistas do mundo inteiro na Casa de Retiro Vila Betânia, em Porto Alegre. Foram 14 dias em imersão, discutindo sobre as causas estruturais da saúde e da doença, compartilhando experiências de ativismo, descobrindo novas formas de organização para combater as injustiças sociais. David Sanders era um dos professores do curso. Chegou um pouco depois, mais perto do Congresso de Epidemiologia, para o qual era convidado. Era noite, e recebi um SMS (Short Message Service) no telefone celular de um número internacional dizendo: "Why am I away from everyone? Am I in quarantine?" ("Por que estou longe de todo mundo? Estou em quarentena?"). Era o David, reclamando porque estava em um hotel cinco estrelas, longe dos ativistas e da energia do Movimento. Ele queria estar ali conosco, nos quartinhos compartilhados, com banheiros coletivos. No dia seguinte, ele veio. $\mathrm{O}$ 'famoso professor' era também um ativista igual a cada um de nós. $\mathrm{E}$ ele ficava tão feliz com tanta gente jovem ao redor. Amava ensinar, e tinha o dom de fazê-lo de forma horizontal, não só nas aulas, mas nos almoços, nos lanches, sentado em roda, no assento do ônibus. Conversar com ele era sempre uma aula. E ele ficava tão à vontade 
em um ambiente simples como aquele, quanto em um ambiente formal e grandioso, como o do pomposo congresso internacional. Sabia muito bem falar e se portar com interlocutores tão diferentes. E conseguia ser, com poucas palavras, sempre direto e claro, tocando exatamente no ponto de desacomodação. Era um grande e talentoso provocador. Nesse espírito, foi para as ruas de Porto Alegre manifestar, em total solidariedade ao Conselho Municipal de Saúde, sua reivindicação na defesa pelo direito à saúde.

Em uma das conversas que tive com ele, compartilhei uma inquietação sobre a minha experiência de ter trabalhado em Angola: " $O$ que ficou, de fato, do trabalho que desenvolvemos lá? Serviu para alguma coisa?". Sem pensar muito, ele respondeu: "Isso é mais difícil de saber, mas uma coisa é certa. Você nunca mais será a mesma. Sua prática está transformada para sempre". Daquele jeito claro e certeiro, característico. Ele falava frases com ponto final. Terminava e a gente ficava pensando. Nunca mais esqueci.

Em outra ocasião, durante mais uma edição do curso da IPHU em Havana, Cuba, em 2009, conversamos em um trajeto de ônibus. Estávamos indo para o jantar organizado pelos anfitriões cubanos. Ao chegar, em um local bem arrumado, destoante da paisagem mais comum da cidade, reclamou, com seu sarcasmo peculiar, porque estávamos indo para um 'lugar chique'. "O que vamos fazer aqui?".
Mas depois se divertiu, jantou, dançou. Mas não podia deixar de evocar a sua provocação.

David era assim, estava sempre à frente do seu tempo e do pensamento. Provocativo, não se contentava com meias respostas. Assertivo, tinha o dom de falar sobre coisas complexas em uma linguagem simples e clara, que todo mundo entendia. Transformou as ideias de muita gente pelo mundo afora. Nos vimos pela última vez em 2016, em Vancouver, durante uma reunião da pesquisa 'Engajamento da sociedade civil para a Saúde para Todos', da qual ele era um dos pesquisadores principais. Uma convivência agradável, era workaholic, mas apreciava muito os momentos de descontração, encontros sociais, sempre interessado nas pessoas, querendo saber como estava a família. David deixou saudades e muitos ensinamentos, que continuarão a mudar o mundo, assim como ele queria. Na sala de aula, nos livros e artigos, nas reuniões por Skype, nas inúmeras viagens, nas excursões, nas caminhadas, nas refeições, na delicadeza do encontro, sentiremos tua falta, David, e faremos ecoar o teu grito em todos os idiomas e geografias. Health for all now!

\section{Colaboradora}

Giugliani C (0000-0002-2652-5214)* é responsável pela elaboração do manuscrito.

\section{Referência}

1. Sanders D. The Struggle for health: Medicine and the Politics of Underdevelopment. Macmillan Publishers LTD: Hampshire; 1985.
${ }^{\star}$ Orcid (Open Researcher and Contributor ID). 